Jeyhun Rzayev

ADA University

Gulana Aliyeva

ADA University

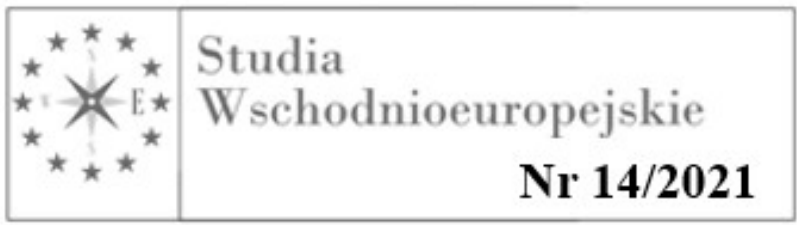

Narodowa Akademia Nauk Azerbejdżanu

\title{
Historical, Cultural and Archeological Review of Karabakh Region of Azerbaijan
}

All in green meadows, all in blooming gardens,

That's why they call it - Karabakh, A magnificent outfit is everywhere pleasing to the eye. Baghdad and Shiraz cannot compare in beauty with it... ...Radiant, gratifying, sparkling land, If the world is heaven, then it is more beautiful than heaven. A blessed shelter, a stately space, Where ears of corn lead, rustling, conversation...

Mir Hamza Seid Nigyari - I thank you, Karabakh

$\mathrm{T}$ he territory of Karabakh includes Lachin, Kalbajar, Shusha, Khankendi, Khojaly, Aghdam, Yevlakh, Barda, Terter, Aghdere, Xojavend, Fizuli, Zengilan, Gubadly and Jabrayil regions. As a result of military aggression by Armenia, more than $20 \%$ of the territory of Azerbaijan was occupied during Karabakh War I (1991-1993). During this conflict, approximately 900 settlements were plundered, burned and destroyed. More than 927 libraries, 464 historical monuments and museums, about 100 archeological monuments, 6 state theaters and concert studios were destroyed in the occupied territories of Azerbaijan. More than 40 thousand valuable items and rare exhibits were stolen from the looted museums. So, after the complete destruction of Kalbajar Historical museum, rare gold and silver jewelry, carpets woven in the past centuries, included in the museum's exposition, were taken 
to Armenia. The same was the fate of Shusha Historical Museum, Agdam Museum of Bread and Zengilan Museum of Stone Monuments.

Karabakh carpets stolen from Shusha city, which had been held under occupation for almost 30 years, were displayed at National Museum-Institute of Architecture in Yerevan on February 20, 2021. These exhibits of the Shusha Carpet Museum were taken from Shusha city to Armenia on November 1, 2020. The oldest of the carpets is about 350 years old ${ }^{1}$.

In the period of antiquity, Caspians, Utiy, Gargars and other Albanian tribes lived in the Karabakh zone, information about which has been preserved by several ancient authors. The areas of their residence were historically the territory of Caucasian Albania, as evidenced by the settlements and necropolises of the ancient period identified and investigated here, showing the absolute identity of the objects of material culture found on the right and left banks of the Kura. The territory of residence of these tribes in antiquity and the early Middle Ages was a part of the Albanian provinces of Uty, Arsag and Paytakaran. In his work "Ancient Caucasian Albania", K. Aliyev, referring to G. Khubshman's research, reports that Paytakaran corresponds to Caspian, Arsag belonged to Albania, but was later taken away, and Uty corresponds to Pliny and Ptolemy's Authena².

Since the end of the $6^{\text {th }}$ century $\mathrm{BC}$, ancient authors had provided information about the tribes living in the territory of Albania. The first author among them was Hecateus of Miletus. He reported on the existence of the tribes of the Mugs and Caspians in Azerbaijan $^{3}$. Later, Herodotus in his work "History", telling about the Achaemenid empire, reports about the Caspian tribe, which lived on the territory of the eleventh satrapy. Herodotus reports on the population, political events, religion, social relations of the tribes of the ancient period on the territory of the future states - Albania and Atropatena. Ptolemy's work named 29 settlements of Albania. However, based on the coordinates he received; the location of these settlements was extremely difficult. According to Pliny's information, Albania covered the territory from the Caucasus Mountains to the mouth of the Kura and was called "mare Albanum". He wrote, "At the very edge of the strait lives the Scythian people of the Udins; behind them on the coast are the Albanians, who, according to a legend, came from Jason, and along which the sea in front of them is called Albanian. This tribe, settled in the Caucasian

\footnotetext{
1 L. Ismayilova, Armenia to Display Stolen Azerbaijani Carpets, za: https://www.azernews.az/aggression/176325.html (2/02/2021).

${ }^{2}$ K. Aliyev, Ancient Caucasian Albania, Baku1992, p. 7.

${ }^{3}$ K. Trever, Historical and Cultural Review of Caucasian Albania (IV century BC - VIII century BC), MoscowLeningrad 1959, p. 48.
} 
mountains, reaches, as it was said, the Kura River, [which is] the border of Armenia and Iberia"4.

Strabo is the first of the ancient authors who devoted a separate chapter to Albania in his "Geography". His work was written after the campaigns of Lucullus and Pompey. According to various sources, he used the works of F. Mitelensky, who accompanied Pompey. In addition, Strabo described the works of Heraclides and Patroclus. It is also known that he used eyewitness accounts of the campaigns ${ }^{5}$.

Describing the settlement of the Albanians, Strabo wrote, "They live between the Iberians and the Caspian Sea; in the east, their country is adjacent to the sea, and in the West, it borders on the Iberians. As for the other sides, the northern one is surrounded by the Caucasus Mountains (because these mountains rise above the plains and are called, especially their parts that are near the sea, the Keravni Mountains) ..."6

According to the Armenian and Albanian written sources of the $5^{\text {th }}-8^{\text {th }}$ centuries, the Nahangs of Uti, Arsag and Paytakaran in the $1^{\text {st }}-7^{\text {th }}$ centuries were Albanian, and the territory of Albania extended in the south to the Araks River ${ }^{7}$.

Armenian historiography also reports that the regions of Uti, Arsag, Paytakaran were originally Albanian. In the $2^{\text {nd }}$ century BC, Armenian king Artashes I annexed a number of neighboring regions to Armenia, including the right bank of the Kura - Sakasena, Uti, Arsag and Paytakaran. Paytakaran remained a part of Armenia until 338, and Arsag and Uti until 387, after which they were reunited with Albania (Strabo, M. Chamchyan, S.T. Yeremyan). It is important to notice that S.T. Eremyan in the previously created atlas included all three regions in Albania in the $2^{\text {nd }}$ century $\mathrm{BC}^{8}$.

\section{Cultural Identities of the Both Banks of the Kura River}

Based on researched monuments of Karabakh, such as Galatepe, Gurdtepe (Agjabedi), Garatepe, Tezekend (Beylagan), Garakopektepe (Fizuli), Uzerliktepe (Agdam), and the burial grounds of Toyretepe, Garakobar, Giyamadinli, Govurgala, Yaldili and others, the authors can conclude that on the territory of Caucasian Albania between the Kura and Araz rivers,

\footnotetext{
${ }^{4}$ Pliny Secund, Book 6 Chapter 13, [w:] News of Ancient Writers about Scythia and Caucasus, V. Latishev (ed.), 'ВДИ' 1949, No. 2 p. 291.

${ }^{5}$ L. Gratsianskaya, Strabo's Geography, ‘Древнейшие государства на территории CССР' 1988, No. 1 р. 77.

${ }^{6}$ Strabo, Geography Book XI Chapter 4,1, p.34.

7 F. Mamedova, On Some Questions about Historical Geography of Albania in the $1^{\text {st }}$ Century BC, 'Историческая география Азербайджана' 1987, №.2 p. 7.

${ }^{8}$ S. Yeremyan, seven maps to The History of Armenians Part 1, Yerevan 1952.
} 
including the lowland and mountainous parts of Karabakh, a common Albanian culture was formed in the ancient period. By the analysis of archaeological materials, the authors compare the artifacts discovered from Albania's ancient monuments located on the right side of the Kura river. These include labor instruments, weapons, glassware, decorative items, metal coins and ceramics. The analysis of archaeological materials confirms the close similarity between the material culture of Karabakh and the left bank of the Kura river and allows characterization of the cultural and economic life of the Albanian tribes in the mentioned region.

Considering that the mountainous part of Karabakh was under occupation from 1992 and there was no opportunity to conduct any research studies in that area: all the research work was done in lowland Karabakh, including the frontline. The investigation of the fortified cities, settlements and burial grounds of Lowland Karabakh shows that they, especially the fortified settlements, have identical urban planning principles and construction techniques with the settlements on the left bank of the Kura. For example, the walls of the ancient period of Galatepe are similar to the walls found in the excavations of ancient Shamakhi, Gabala, Dzhanahara (Khachmaz) by the size of bricks, the principle of masonry, etc.

The unity of the culture of both banks of the Kura river is also traced by the discovered column bases. So, on the right bank of the Kura river, the archeologists were investigating the bases of the columns found in Agjabedi (Galatepe ${ }^{9}$, Gurdtepe ${ }^{10}$ ), Beylagan (Tezekend, Garatepe ${ }^{11}$ ), Agdam (Boy-Akhmedli) and Barda (Shatyrly). The investigated column bases are similar to those found on the left bank of the Kura river, namely in Gabala ${ }^{12}$ (Chaggalli), Shamakhy ${ }^{13}$ (Khynisly), Shamkir ${ }^{14}$ (Gurbantepe) and Gazakh (Sarytepe).

The rich ceramic material shows the similarity of the material culture of Lowland Karabakh with the monuments throughout the territory of Caucasian Albania. For example, a jug of oinokhoya found in the village of Yeni Garadolag, Agjabedi region, belongs to the Yaloylutepe culture and is mainly found on the left bank of the Kura.

\footnotetext{
${ }^{9}$ T. Aliyev et al., The Research Studies in Ancient City and Necropolis Galatepe (Agjabedi), 'Azorbaycanda arxeoloji tədqiqatlar - 2011', Baku 2012, p. 226-234.

${ }^{10}$ T. Rasuloghlu, Archeological Monuments along Gavurargh, Materials of the Scientific Session Dedicated to the 100-Year Anniversary of the Eminent Azerbaijani Archeologist S. Gaziyev, Baku 1994, p. 52-53.

${ }^{11}$ H. Jafarov, On the Investigations on Garatepe Hill, 'Археологические и этнографические изыскания в Азербайджане (1980-1981)', Baku 1986, p. 52-56.

${ }^{12}$ I. Aliyev \& F. Gadirov, Gabala, Baku 1985, p. 61.

${ }^{13}$ D. Akhundov, The Architecture of Ancient and Early Medieval Azerbaijan, Baku 1986, p. 218.

14 I. Babaev, G. Mehnert G \& F. Knaus, The Achaemenid residence on Gurban Tepe Excavated near Karajamirli, 'Archaologische Mitteilungen aus Iran and Turan', Berlin 2010, p. 292-294.
} 
The analysis of the archaeological materials pictures life in the cities of Albania in the period of antiquity. These cities were administrative and trade and craft centers with a developed money circulation. In the cities of Albania were developed such types of crafts as pottery, metallurgy and metalworking, jewelry, glass making, as well as weaving and leatherworking. The development of the Albanian settlements was mainly fostered by the trade routes passing through their territory. Most of these routes went through the waterways of the Kura river.

The culture of Hellenism is known to impact the cultures of different peoples, had occupied a dominant position in Albania for a long time. Hellenistic masters worked on the orders of the Scythian kings; their products moved to Central Asia, and Greek wool stitching penetrated into Mongolia. It is not surprising that traces of such a rich culture can be tracked in the territory of Caucasian Albania. The information about the close economic and cultural ties of the inhabitants of Albania with the ancient world is available from Strabo, Pliny, Ptolemy and others.

The analysis of ceramic products enables the authors to make a number of conclusions on the history of material culture. First of all, pottery is almost always local in nature and reflects local elements of culture, according to which the influence of neighboring regions is also well determined. The classification and analysis of ceramics show that throughout the history of Albania in all its territory there was no stability in the typology and production of pottery. This mainly depended on the nature and level of productive relations which did not develop consistently throughout the country. The level of development of pottery production in the central regions of Albania was higher than in its periphery. The common traditional forms of vessels were developed in the central regions of Albania. In the $2^{\text {nd }}-3^{\text {rd }}$ centuries, some changes were observed in the ceramic production: a number of types fell out of use, and the influence of neighboring cultures increased in the border areas. The numerous ceramic complexes extracted from the monuments of Albania contribute to the gradual study of this production, as well as help in the study of historical and cultural issues of the Albanians.

A plethora of archaeological materials shows that ceramics, glass and metal vessels, including decorative items from settlements and burial grounds both banks of the Kura are almost identical. This fact proves the existence of a common material culture of Albania within its historical boarders from Southern Dagestan in the north to the Araz river in the south. 


\section{Archaeological Monuments of The Liberated Lands}

As a result of the military aggression of Armenia against Azerbaijan in the years 19911994, the Nagorno Karabakh Autonomous Region of Azerbaijan and 7 adjacent regions (Agdam, Jabrayil, Fizuli, Kalbajar, Gubadli, Lachin and Zangilan) were occupied. Armenian aggressors had brutally destroyed the cultural masterpieces that form the cultural heritage of Azerbaijan in the occupied territories. In those lands, they plundered and set alight 12 museums, 6 art galleries and 9 palaces of historical importance; 152 sacred places and temples, including 62 mosques remaining in the occupied territories had fallen victim to Armenian aggression. About 4.6 million books and samples of rare manuscripts were destroyed in 927 libraries which were razed to the ground or set on fire. It is impossible to assess the exact damage caused by Armenian aggressors to the cultural sites of Azerbaijan in Nagorno Karabakh and neighboring regions since the plundered or destroyed riches are considered to be the exceptional masterpieces not only of Azerbaijan but also of the whole human civilization.

Besides the moral and psychological trauma caused to the population, according to the preliminary calculations, as a result of aggression of the Armenian Armed Forces, the damage inflicted on the Azerbaijani economy exceeds billions US dollars. Shusha, Agdam, Fizuli, Jabrayil, Zangilan and Gubadli cities were completely ruined and plundered by the Armed Forces of Armenia. Today's views of Agdam and Fizuli cities resemble Hiroshima and Nagasaki cities destroyed by an atomic bomb in 1945. After liberation of those lands from Armenian occupation Azerbaijan demonstrated all damages made by aggressor and the world eyewitnesses the great cultural terror. There existed over thousand Azerbaijani residential settlements, hundreds of historical and architectural monuments, caravanserais, mansions, mosques, mausoleums, cemeteries, sepulchers and tombstones. The cultural terror against Azerbaijani heritage expanded not only to the occupied territories of Azerbaijan but also to Armenia itself. As a result of the ethnic cleansing of Azerbaijanis and act of vandalism against the historical monuments committed by Armenians in the 20th century, Armenia became a monoethnic state and all the historical and architectural monuments reflecting the existence of Azerbaijanis were wiped off the map, and the cemeteries were demolished.

There are several thousand historical monuments in Karabakh. They include historical buildings, mosques and churches. The territories of Azerbaijan occupied by Armenia in the 90s, during Karabakh War I, have vivid evidence for belonging to Azerbaijan. In Karabakh, there are numerous khanagahs, monumental structures, 
medieval necropolises that reveal the names of architects, scientists, sculptors, calligraphers, carvers and sheikhs of the Sufi orders, including the founders of architectural schools, who created a number of beautiful works of a peculiar architectural-constructive style of mausoleums.

After Karabakh War II in 2020 and recent liberation of the lands, Azerbaijan plans to organize archaeological research groups of local and international archeologists that will continue to study the history of Karabakh more actively. The greatest obstacle for the time being is not current pandemic situation in the world but the fact that historical monuments and even cemeteries are mined. About 800 monuments of architecture, archeology, landscape gardening and decorative and applied arts are included in the list of structures under the state protection. Among these, 13 are monuments of world importance: mausoleum of Gulu Musa oglu (1314) in Aghdam region, Genjasar (1238) and Khudaveng $\left(13^{\text {th }}-17^{\text {th }}\right.$ centuries $)$ monasteries in Kelbajar region, 11and 15 -span bridges $\left(12^{\text {th }}-15^{\text {th }}\right.$ centuries $)$ on the river Araz in the Jebrail region, a monument of medieval urban planning - the city of Shusha, Azykh and Taglar caves - the habitat of a primitive man of the Paleolithic period in Fizuli region, Chalagantepe and Leylantepe settlements of the Eneolithic period, Uzerliktepe in the Aghdam region and complexes of barrows of the Bronze and Khojali and Jabrail regions.

Azykh is the largest cave in Azerbaijan, located in Khojavand region, at a height of $900 \mathrm{~m}$. There are 6 cells connected with each other. Azykh is one of those rare caves of the Palaeolithic period which started to be explored by the Azerbaijani researchers in $1960^{15}$. In 1968, there was found a fragment of a lower jaw belonging to the ancient man who lived 350 thousand years ago (Ashel period). This is one of the most ancient relics found for the time being. Several cultural layers evidencing the ancient man's long-term presence in Azykh cave were discovered during the excavations carried out in the $\operatorname{spot}^{16}$. Primitive people living there were engaged in collecting, hunting and fishing. A number fireplaces with a large amount of charcoal and ash remains were revealed there. Azykh cave confirms that the territory of Azerbaijan was obviously human inhabited 1 million years ago ${ }^{17}$. During the period of occupation of the Armenian Armed Forces, the archaeologists of the Armenian Academy of Sciences had been conducting "research" in what they used to call "Azokh". In the fall of 2020, as the outcome of Karabakh War II, Azykh village was liberated from the

\footnotetext{
${ }^{15}$ M. Huseynov, On the Results of the Archeological Excavations in Azerbaijan, Baku 1965, p. 17.

${ }^{16}$ M. Marjanli (red.), Azykh Cave, https://books.irs-az.com/garabagh_ru/index.html, p. 14-15 (2/02/2021).

${ }^{17}$ V. Aliyev, Karabakh (Ancient Times), Baku 2010, p. 18-19.
} 
occupation, providing Azerbaijani researchers and archeologists with an opportunity to continue their investigation of the area.

Another historical monument in the territory of Khojavand region relating to the Mousterian culture is Taghlar cave camp, the most immense cave camp. The cave is very important in terms of remains of material culture, stratigraphy and long-term residence. Taghlar cave camp is located on the left shore of the Guruchay River. Between 1963 and 1987, the Paleolit archaeological expedition had been conducting excavations in Taghlar camp $^{18}$. As a result of excavations more than 8000 stone tools and more than 2000 animal bones were found there. For the time being, 6 cultural layers have found out in sediments of Taghlar camp leaving a chance for more layers to be found in future. Unlike all the other monuments existing in the entire Caucasus and the Near East, Taghlar was the only site that had a permanent settlement.

A valuable example of the Elkhanids' memorial architecture has survived in Khachin Turbatli village of the Aghdam Region. An inscription above the front door of this site, popularly called "Sari Musa Tomb", says, "Master Shahbenzeri has built this tomb for the deceased Gulu Khaja Musa Oglu, who needs Allah's mercy”. According to this inscription, the construction of the tomb was completed on July 15, 1314. Most probably, the tomb of the person, who was an influential figure of Azerbaijan's historical Khachin district, had determined the village's name. Gutlu Khaja Musa Oglu tomb has dynamic volume composition, which is typical for the tower-shaped tombs of Azerbaijan. However, the monument embraces the original features of Aran, especially Garabakh architecture in both the construction technique and artistic design of the details. The tomb has a double constitution of the under vault and overground chamber. In 1993, after the occupation of Aghdam, the Armenian vandals erased the wall paintings and inscriptions of the tomb and carved small cross paintings and Armenian inscriptions in stone instead ${ }^{19}$.

Khudavang, or Dedeveng, located in the Vang village of Kalbajar region, on the left bank of the Terterchay river, is one of the largest and most beautiful examples of Azerbaijan's Christian architecture. According to a legend, Apostle Thaddeus, the first Christian missionary in the Caucasus, was buried there. Therefore, the complex is supposed to have been founded in the $4^{\text {th }}$ century. The complex was mainly constructed in the $13^{\text {th }}$ century, in

\footnotetext{
${ }^{18}$ A. Jafarov, Multilayered Taghlar Settlement of the Mustye Period in Azerbaijan, 'Современная археология', Baku 1978. No. 4, p. 239-245.

19 Armenian $\quad$ Vandalism: Azerbaijani Monuments in Captivity, https://www.armenianvandalism.az/en_aghdam.html, Presidential Library (C) 2015 (2/02/2021).
} 
the reign of Albanian king Vakhtang. The monastery complex currently includes more than twenty buildings and ruins. The main church was built in 1214 by Arzu Khatun, king Vakhtang's wife. Dominating throughout the complex, its dome high and space majestic, the church is one of the Caucasian-Albanian Christian masterpieces of architecture. It is believed that Arzu Khatun and her daughters painted the interior murals. There are fine carvings on the western and northern sides of the church. The main religious part of the complex consists of seven spaces, different in terms of composition, but mutually supplementing.

The main building of the complex is the Boyuk Hasan Church. In the southern part, there are civil buildings such as a palace and working and living premises on the slope. The complex buildings fully demonstrate the centuries-old construction culture and versatile types of Azerbaijan's Christian Architecture. Many construction inscriptions have survived in the Khudavang Complex; a number of names indicated there, such as Arzu, Tursun, Seyti, Asan, Avag, Shams, Altun, Aghbuh, Garagoz, etc., are considered to refer to the builders of a Turkic ethnicity.

The Ganjasar Monastery located in Vangli village of the Kalbajar region, along with being the headquarter of the Caucasian Albanian Catholicoses, was the shrine of the Jalalids, Albanian kings and catholicoses. The Ganjasar Monastery, known as the Khaznadagh Temple in scientific literature, was mostly constructed in the $13^{\text {th }}$ century. The hill on the Khachinchay river, where the monastery is located, was sacred in the pre-Christian era and turned into a pagan temple. From the $13^{\text {th }}$ to the $19^{\text {th }}$ century the Ganjasar Monastery had been the religious and cultural center of Caucasian Albania. The complex consists of a church, private entrance hall and supporting buildings. The complex is castle walled, the southern and western parts having a gate each. Cells and supporting rooms join the northern and southern walls. Hasan Jalal, the Albanian king, founded the church next to the southern gate of the complex in the period of 1216-1238.

The Seljuk and especially Elkhanids' periods had a considerable influence on the concept and construction of this valuable monument. Its majestic volume-and-space composition, rich and subtle artistic design, as well as the highest-quality construction relates to the economic power of Elkhanid state.

As the period of Elkhanids' reign was the top of Azerbaijan's medieval architecture, the Ganjasar Monastery was also the masterpiece of Azerbaijan's Turkic-Christian architecture. From 1511, the Ganjasar Monastery had been the headquarter of the Albanian Catholicoses. In 1836, Armenians succeeded in abolishing of the Albanian Catholicity by the decree of the Russian Empire and subordinating the Albanian churches to Echmiadzin 
Catholicity. Then, falsifying the history, they presented the Albanian religious monuments as Armenian religious monuments to the world ${ }^{20}$.

For 30 years, Armenians managed to replace the Albanian inscriptions on the walls of churches with their own. It should be noted that in 1836 the Russian Emperor Nicholas I liquidated the Autocephalous Albanian Church by his decree and ordered to give the temples and property to the Armenian Gregorian Church. The abolition of the Albanian Church was the beginning of the policy of aggressive appropriation of the Albanian ethnocultural heritage and its transformation into "Armenian".

It is known that in the $15^{\text {th }}$ century, Armenian clergy came to the South Caucasus in search of their homeland and with the desire to create a state. Having rented the Albanian monastery "Uchmuzzin" ("three man reading azan") - the present Echmiadzin - from the ruler of Garagoyunlu Jahan Shah in 1441, they transferred the Armenian Catholicism shrine from the city of Sis in Cilicia to this monastery. After that, Armenian missionaries moved there. Later, the Armenians changed the name "Uchmuazzin" to "Echmiadzin". The monastery became the religious center of Armenians in the South Caucasus.

Another significant architectural monument of the region is Khudafarin Bridge. Though many bridges were built across Araz river for centuries, only two of them in the Jabrayil region have survived. Almost 750 meters away from each other, they are located in one of the Araz's best fords, the Khudafarin Gorge. In fact, there are large rocky massifs in the expanding bed. Those rocks made a reliable fundament for the bridge beams. The 15arched long bridge is built of bricks and river stones. The total length is nearly 200 meters; the width is 4.5 meters; the maximum height over the river surface is 12 meters; the longest beam pass is 8.70 meters; and the shortest beam pass is 5.80 meters.

The other, 11-arched Khudafarin Bridge, located upriver, is entirely stone-built and covered with good-hewn stone plates. It is assumed that this bridge was rebuilt in the $13^{\text {th }}$ century on the ruins of a more ancient one. The total length is 130 meters; the width is 6 meters; and the maximum height over the river surface is 12 meters. As only three middlespans of the bridge have survived, it is popularly called "Sinig Korpu" (the Broken Bridge).

Khudafarin Bridges are universally valuable sites due to the world-important historical events, beautiful landscape, high level engineering performance, etc. The parts

\footnotetext{
${ }^{20}$ Ibidem, https://www.armenianvandalism.az/en_kalbajar.html (2/02/2021).
} 
of transcontinental roads including the Great Silk Road, the bridges were useful not only for domestic and international relations but also for those between continents.

Related to the monuments of the late Middle Ages, Garghabazar caravanserai was built in 1681 at the hillside, in the center of Garghabazar village of Fizuli district. Caravanserai building is 23.7 meters wide, 34.7 meters in length. Garghabazar caravanserai is a single-storeyed multi-yarded asymmetric building with arched rooms like corridors. The caravanserai was named Garghabazar after the village it was built in. Sometimes, this historical monument is also referred to as Shah Abbas caravanserai. The architect of the monument remains unknown. Concerning its architectural style, Garghabazar caravanserai bears resemblance to the architectural traditions of the Albanian period. There are two large slabs of stone on the right and left sides of entrance, in front of the guard rooms. Apparently, the guards used to stand on those stones and watch the loads of the caravans. Caravanserai is considered an immovable historical monument of Azerbaijan. After the occupation of Garghabazar village, the Armenians transformed this historical and architectural monument into a cowhouse.

Another architectural monument attributed to the $17^{\text {th }}-18^{\text {th }}$ centuries is "Imam Huseyn" Mosque situated in Zangilan city. The mosque is supposed to be built in the period of the Safavids. Its area dimensions were $12 \times 20$ meters. There was a sanctuary and a niche inside the mosque. Mainly the local limestone was used in the construction. The vaulted door of the mosque was opened to the east and bore an inscription "Imam Huseyn". The Mosque was demolished by the Armenian vandals ${ }^{21}$.

During the Islamic period, a large number of mosques and minarets were built in the Karabakh region of Azerbaijan. According to the official data, today there are 403 historical and religious monuments on the territory of Karabakh, of which 67 are mosques, 144 are temples, 192 are sanctuaries. Unfortunately, 63 mosques (13 in Shusha, 5 in Aghdam, 16 in Fizuli, 12 in Zangilan, 5 in Jebrail, 8 in Gubadli and another 8 in Lachin) were completely destroyed, four more were partially ruined ${ }^{22}$.

The Armenians also destroyed the ancient centers of civilization in Agdam region. The monument to Uzerliktepe, the Mausoleum of Gutlu Sama Musa in the village of Khachinderbend (the $14^{\text {th }}$ century), the tomb in the village of Kengerli (the

\footnotetext{
${ }^{21}$ Ibidem, https://www.armenianvandalism.az/en_zangilan.html (2/02/2021).

${ }^{22}$ S. Kazimova, The Monuments of Cultural and Religious Heritage of Liberated Karabakh, https://moscowbaku.ru/news/culture/pamyatniki_kulturnogo_i_religioznogo_naslediya_osvobozhdennogo_karabakha/ $(2 / 02 / 2021)$.
} 
$14^{\text {th }}$ century), the tomb erected in honor of the daughter of Natavan Khan and her son (the $19^{\text {th }}$ century), the Shahbulag fortress and other historical and cultural objects were destroyed there.

One of the monuments, located at the intersection of the foothills of the Karabakh mountain range and the Mil-Karabakh plain, is Nargiztepe. The research studies of this great strategically important monument were conducted in a hard condition due to its location right in the frontline.

The archaeological research at Nargiztepe began in 2013. Exploratory surveys conducted to investigate the stratification of Nargiztepe in northern part of the settlement showed that the monument consists of three cultural phases: Middle Bronze, Antique and Medieval Ages. Rare Early Iron Age pottery fragments (rim, body and handle of black glossy containers) encountered in the monument are an indication for the existence of a related cultural layer of this period. The wall, as well as the Middle Bronze Age pottery sparsely found in this layer show that Nargiztepe was a fortified town site $^{23}$.

It should be mentioned that in antiquity and the Early Middle Ages, Nargiztepe was a part of the Arsag province which belonged the ancient Azerbaijanian state of Caucasian Albania and played an important role in the cultural and economic life of the country. Throughout the Middle Ages, Nargiztepe had been inhabited by Turkic tribes. Grave monuments, toponyms of Turkish origin, folklore samples and material artefacts confirm this fact.

The district center Martuni, which was under the occupation for about 30 years, the settlement of Kuropatkino and the remains of the village of Muganly, which are all destroyed and burned by vandals, are visible from this elevation.

During the prospective exploration, German experts helped the authors to implement a number of practical works: Geodesist A. Kvast used modern technical equipment to draw a topographic plan of the monument, and the geophysicists J. Fassbinder and F. Becker drafted a magnetometry map of the area. In order to create a 3D image of the Nargiztepe site, the technician J. Krumnow conducted primary works ${ }^{24}$.

Primary excavations at the current site of the Nargiztepe complex showed that a necropolis of jar burials was located there. Their safe location under the hard-rocky soil at a considerable depth on a slightly slanting slope caused them to remain intact. Future

\footnotetext{
${ }^{23}$ T. Aliyev, B. Ibrahimli \& G. Aliyeva, The Complex of Nargiztepe Monuments in Karabakh, Baku 2017, p. 12.

${ }^{24}$ B. Helwing, A. Ricci \& T. Aliyev, Mounds and Settlements in the Lower Garabakh - Mil Plain, Azerbaijan, 'Human Development in Landscapes Graduate School at the University of Kiel', Bonn 2012, p. 67-77.
} 
archaeological excavations at the ancient necropolis can play an important role in the study of the political, socioeconomic and cultural life of Caucasian Albania.

Wide scale archaeological excavations are planned to be conducted in Nargiztepe. This will allow for obtaining a wider range of materials on the monument and provision of an important new contribution to the study of the rich history of Karabakh.

One of the multi-layered settlements of Karabakh is Garakopektepe near the city of Fizuli, between the Guruchay and Kondelenchay rivers. In 1895, a German researcher of Shusha Realni School E. Roesler carried out the first surveys in Garakopektepe, when during the excavations square burnt bricks were revealed ${ }^{25}$. In 1965, the Fizuli detachment of the Archeology and Ethnography Sector of the Institute of History of the Academy of Sciences of the Azerbaijan SSR under the leadership of G.S. Ismailzade began a stationary study of the Garakopektepe monument, where the cultural deposits from the Early Bronze period to the early the middle ages were revealed ${ }^{26}$.

As a result of the archaeological excavations in the ancient cultural layer of the monument, $3 \mathrm{~m}$ thick, the remains of a large settlement were discovered: the foundations of rectangular buildings made of river cobblestones, the remains of hearths, household jugs and ceramics of the $4^{\text {th }}-3^{\text {rd }}$ centuries $\mathrm{BC}$. The walls and floors had a thick layer of clay. F. Osmanov concluded that at that time the technique of construction of household and public buildings erected on stone documents had already been improved ${ }^{27}$. The described premises, as well as other buildings of the Garakopektepe settlement, were filled with a thick layer of ash, charcoal, burnt earth, stones and pieces of clay, testifying that there was a strong fire, as a result of which the city ceased to exist. G. Ismayilzade suggested that the end of the city's existence was associated with the eastern campaign of Alexander Macedonian, when one of his Greco-Macedonian garrisons was able to reach the southern borders of Caucasian Albania. Taking into consideration that a medieval cultural layer, about $2.7 \mathrm{~m}$ thick, was also discovered as a result of archaeological excavations, it can be argued that the city was renewed and continued its existence until the Mongol invasions.

The materials found at Garakopektepe indicate a significant number of the residents in the area. The reason for selecting this monument as residential area throughout various historical periods was the advantageous strategic position of Garakopektepe. Quite

\footnotetext{
${ }^{25}$ E. Rösler, Den archäologisch - ethnologisclien Bericht aus Schuscha, Shusha 1897, p. 292.

${ }^{26}$ G. Ismayilzade, Garakopektepe: The Unique Ancient Monument, 'Azərbaycan arxeologiyası', No. 3-4, Baku 2000, p. 74-76.

${ }^{27}$ F. Osmanov, History and Culture (IV Century BC - III Century AD), Baku 2006, p. 207.
} 
a favorable location of Garakopektepe turned the city into one of the main strongholds of Caucasian Albania. It was located on the southernmost border of Albania, at the intersection of the most ancient routes connecting the Caucasus with many countries of the East, including the Iranian Highlands.

Unfortunately, due to the fact that the site had been under the Armenian occupation about 30 years, it was impossible to conduct any archaeological excavations and investigations in Karabakh. Despite the demands expressed in UN Security Council Resolutions Nos. $822,853,874$ and 884 on the need to recognize the territorial integrity of the Republic of Azerbaijan and liberate the occupied territories of Azerbaijan without preconditions, the Republic of Armenia continued to pursue its aggressive policy. The Republic of Armenia, grossly violating the provisions of the Hague Convention "On the Protection of Cultural Property in Time of Military Conflicts" and the Paris Convention "On the Illicit Traffic in Cultural Property", was plundering the cultural property of Azerbaijan. Today almost all of the historical heritage of Karabakh needs to be restored, since during the years of the Armenian occupation they were completely or partially destroyed.

\section{Streszczenie:}

Artykuł dotyczy zabytków kultury materialnej i duchowej Azerbejdżanu położonych na terenie Karabachu, zarówno na równinie, jak i w strefie górskiej. Należy zauważyć, że ze względu na to, że terytorium to znajdowało się pod okupacją Armenii przez około 30 lat, większość zabytków została zniszczona lub mało zbadana w wyniku braku ekspedycji archeologicznych. Głównym argumentem artykułu jest fałszowanie i przywłaszczanie sobie zabytków kultury przez ludność ormiańską zarówno przed wybuchem drugiej wojny karabaskiej, jak i po jej zakończeniu. Artykuł analizuje okres od starożytności, wzmiankę o kaukaskiej Albanii w twórczości takich autorów jak Ptolemeusz, Strabon, Heraklides i in., Badania zabytków kultury materialnej związanych z epoką paleolitu, eneolitu i brązu, a kończąc na wyzwolenie terytoriów Azerbejdżanu spod okupacji ormiańskiej. Ponadto autorzy wspominają o aktach wandalizmu w wyniku ormiańskiej agresji i terroru, wyrządzeniu szkód materialnych, a także o potrzebie renowacji większości zabytków kultury materialnej.

\section{Słowa kluczowe:}

Azerbejdżan, Karabach, starożytne zabytki, dziedzictwo kulturowe, jaskinia Azykh, klasztor Khudaveng, klasztor Genjasar, Garakopektepe, Nargiztepe, most Khudafarin 


\section{Key words:}

Azerbaijan, Karabakh, ancient monuments, cultural heritage, Azykh cave, Khudaveng monastery, Genjasar monastery, Garakopektepe, Nargiztepe, Khudafarin bridge

\section{Bibliografia:}

1. Akhundov D., The Architecture of Ancient and Early Medieval Azerbaijan, Baku 1986.

2. Aliyev I. \& Gadirov F., Gabala, Baku 1985.

3. Aliyev K, Ancient Caucasian Albania, Baku 1992.

4. Aliyev T. et al., The Research Studies in Ancient City and Necropolis Galatepe (Agjabedi), "Azərbaycanda arxeoloji tədqiqatlar - 2011", Baku 2012.

5. Aliyev T., Ibrahimli B. \& Aliyeva G., The Complex of Nargiztepe Monuments in Karabakh, Baku 2017.

6. Aliyev V., Karabakh (Ancient Times), Baku 2010.

7. Armenian Vandalism: Azerbaijani Monuments in Captivity, https://www.armenianvandalism.az/en_aghdam.html, Presidential Library (C) 2015 $(2 / 02 / 2021)$.

8. Babaev I, Mehnert G. \& Knaus F., The Achaemenid residence on Gurban Tepe Excavated near Karajamirli, 'Archaologische Mitteilungen aus Iran and Turan', Berlin 2010.

9. Gratsianskaya L., Strabo’s Geography, “Древнейшие государства на территории CCCP" 1988, No. 1.

10. Helwing B., Ricci A. \& Aliyev T., Mounds and Settlements in the Lower GarabakhMil Plain, Azerbaijan, 'Human Development in Landscapes Graduate School at the University of Kiel', Bonn 2012.

11. Huseynov M., On the Results of the Archeological Excavations in Azerbaijan, Baku 1965.

12. Ismayilova L., Armenia to Display Stolen Azerbaijani Carpets, https://www.azernews.az/aggression/176325.html (2/02/2021).

13. Ismayilzade G., Garakopektepe: The Unique Ancient Monument, 'Azərbaycan arxeologiyası', No. 3-4, Baku 2000.

14. Jafarov A., Multilayered Taghlar Settlement of the Mustye Period in Azerbaijan, “Современная археология”, Baku 1978. No. 4.

15. Jafarov H., On the Investigations on Garatepe Hill, 'Археологические и этнографические изыскания в Азербайджане (1980-1981)', Baku 1986.

16. Kazimova S., The Monuments of Cultural and Religious Heritage of Liberated Karabakh, https://moscowbaku.ru/news/culture/pamyatniki_kulturnogo_i_religioznogo_naslediya_osvoboz hdennogo_karabakha/ (2/02/2021).

17. Latishev V. (red.), “ВДИ” 1949, No. 2.

18. Mamedova F., On Some Questions about Historical Geography of Albania in the $1^{\text {st }}$ Century BC, “Историческая география Азербайджана” 1987, No.2. 
19. Marjanli M. (red.), Azykh Cave, https://books.irs-az.com/garabagh_ru/index.html $(2 / 02 / 2021)$.

20. Osmanov F., History and Culture (IV Century BC - III Century AD), Baku 2006.

21. Pliny Secund, Book 6 Chapter 13, [w:] News of Ancient Writers about Scythia and Caucasus, Strabo, Geography Book XI Chapter 4,1.

22. Rasuloghlu T., Archeological Monuments along Gavurargh, Materials of the Scientific Session Dedicated to the 100-Year Anniversary of the Eminent Azerbaijani Archeologist S. Gaziyev, Baku 1994.

23. Rösler E., Den archäologisch - ethnologisclien Bericht aus Schuscha, Shusha 1897.

24. Trever K., Historical and Cultural Review of Caucasian Albania (IV century BC VIII century BC), Moscow-Leningrad 1959.

25. Yeremyan S., seven maps to The History of Armenians Part 1, Yerevan 1952. 